\title{
Genetic parameters for ultrasound-evaluated carcass and body traits in Anglo-Nubian goats
}

\author{
Parámetros genéticos para las características de la canal y del cuerpo evaluadas por ultrasonido en \\ cabras Anglo-Nubianas
}

\section{Parâmetros genéticos para características da carcaça avaliadas por ultrassom e corporais em caprinos Anglo-Nubianos}

\author{
Luiz AS Figueiredo-Filho ${ }^{1 * \mathbb{D}}$; José LR Sarmento ${ }^{2}$ iD; José EG Campelo ${ }^{2}$ iD; Natanael PS Santos ${ }^{3}$ iD; \\ Luciano S Sena ${ }^{4}$ iD; Tatiana S Torres ${ }^{4}$ (D).
}

\footnotetext{
${ }^{1}$ Instituto Federal de Educação, Ciência e Tecnologia do Maranhão; Rodovia MA 349, Km 2, 65600-992, Caxias, MA, Brazil.

${ }^{2}$ Departamento de Zootecnia, Centro de Ciências Agrárias, Universidade Federal do Piauí;64049-550, Socopo, Teresina, PI, Brazil.

${ }^{3}$ Universidade Federal do Piauí; Av. Manoel Gracindo, Km 1, Planalto Horizonte, 64900-000, Bom Jesus, PI, Brazil.

${ }^{4}$ Universidade Federal do Piauí; 64049-550, Socopo, Teresina, PI, Brazil.
}

To cite this article:

Figueiredo-Filho LAS, Sarmento JLR, Campelo JEG, Santos NPS, Sena LS, Torres TS. Genetic parameters for ultrasound-evaluated carcass and body traits in Anglo-Nubian goats. Rev Colomb Cienc Pecu 2021; 34(1):40-50. DOI: https://doi.org/10.17533/udea.rccp.v34n1a04

\begin{abstract}
Background: Meat goat breeding programs should prioritize the identification and selection of genetically superior animals for traits related to meat quality and carcass yield in order to increase the value of the final product. Objective: To estimate (co)variance components and genetic parameters for ultrasound-measured carcass traits, body size and body weight in AngloNubian breed goats raised in the Mid-North region of Brazil. Methods: (Co)variance components and genetic parameters were estimated using the single and two-trait animal model analyses via Bayesian inference for loin eye dimensions (area, length, and depth), sternal fat thickness, rump height, chest circumference and depth, leg perimeter, and body weight. Results: Heritability estimates were higher when two-trait analyses were used. This finding implies that it is possible to recover part of the additive genetic variance included in the residual variance due to the correlation between traits. Genetic correlations between carcass and body size traits showed different magnitudes. On the other hand, genetic correlations between the traits related to muscularity showed high magnitudes. Conclusions: Body weight was not a good indicator of muscularity; therefore, it is not recommended as a criterion for indirect selection to improve carcass traits of Anglo-Nubian goats. Leg perimeter and chest circumference may be important to construct selection indexes in meat goat breeding programs.
\end{abstract}

Keywords: Anglonubian; animal production; bayesian inference; carcass; (co)variance; genetic correlation; genetic parameters; Gibbs sampling; goats; heritability; meat quality; selection; selection index; ultrasonography.

Received: January 21, 2019; accepted: June 6, 2020

*Corresponding author. Rodovia MA 349, Km 2, 65609-899, Caxias/MA, Brazil. E-mail: luiz.figueiredo@ifma.edu.br 


\section{Resumen}

Antecedentes: los programas de mejoramiento de caprinos de carne deben priorizar la identificación y selección de animales genéticamente superiores para características relacionadas con la calidad de la carne y rendimiento de la canal, con el fin de agregar valor al producto final. Objetivo: estimar los componentes de (co)varianza y parámetros genéticos para características de canal obtenidas por ultrasonografía, características de tamaño y peso corporal en caprinos de la raza Anglonubiana, criados en la región medio-norte de Brasil. Métodos: los componentes de (co)varianza y parámetros genéticos fueron estimados mediante un modelo animal usando análisis uni y bi-carácter vía metodología Bayesiana para las dimensiones del ojo de lomo (área, profundidad y longitud), grosor de la grasa esternal, altura de la grupa, circunferencia y profundidad torácica, perímetro de la pierna y peso corporal. Resultados: las estimativas de heredabilidad obtenidas a partir del análisis bi-carácteristico fueron mayores que las obtenidas a partir del análisis uni-carácteristico. Este supuesto implica que es posible recuperar parte de la variancia genética aditiva incluida en la variancia residual, debido a la correlación entre las características. Las correlaciones genéticas entre las características de canal y las medidas corporales presentaron diferentes magnitudes. Por otro lado, las correlaciones genéticas entre las características relacionadas con musculatura presentaron alta magnitud. Conclusiones: el peso corporal no fue un buen indicador de musculatura; por eso no es recomendado como criterio de selección indirecta para mejorar la canal de caprinos Anglonubianos. El perímetro de la pierna y la circunferencia del pecho pueden ser importantes para la construcción de índices de selección en programas de mejoramiento de carne caprina.

Palabras clave: Anglonubiana; cabras; canal; calidad de carne; correlación genética; (co)variancia; heredabilidad; índice de selección; inferencia Bayesiana; muestreo de Gibbs; parámetros genéticos; producción animal; selección; ultrasonografía.

\section{Resumo}

Antecedentes: programas de melhoramento de caprinos de corte devem priorizar a identificação e seleção de animais geneticamente superiores para características relacionadas à qualidade da carne e rendimento de carcaça, para aumentar o valor ao produto final. Objetivo: estimar componentes de (co)variância e parâmetros genéticos para características de carcaça obtidas por ultrassonografia, características de tamanho e peso corporal em caprinos da raça Anglo-Nubiana criados na região Meio-Norte do Brasil. Métodos: os componentes de (co)variância e parâmetros genéticos foram estimados usando análises uni e bicaracterísticas de um modelo animal via metodologia Bayesiana para área, profundidade e comprimento de olho de lombo, espessura da gordura esternal, altura da garupa, circunferência e profundidade torácica, perímetro da perna e peso corporal. Resultados: as estimativas de herdabilidade obtidas a partir das análises bicaracterísticas foram maiores que as obtidas a partir das análises unicaracterísticas. Esse resultado implica que é possível recuperar parte da variância genética aditiva incluída na variância residual devido à correlação entre as características. As correlações genéticas entre as características de carcaça e as medidas corporais apresentaram magnitudes variáveis. Por outro lado, as correlações genéticas entre as características relacionadas à musculosidade apresentaram altas magnitudes. Conclusões: o peso corporal não se mostrou um bom indicador de muscularidade, de modo que não é recomendado como critério de seleção indireta para melhorar a carcaça de caprinos Anglo-Nubiano. O perímetro de perna e a circunferência torácica podem ser importantes para a construção de índices de seleção em programas de melhoramento de carne caprina.

Palavras-chave: Anglonubiana; amostragem de Gibbs; carcaça; caprinocultura; correlação genética; (co)variância; heredabilidade; indice de seleção; inferência Bayesiana; parâmetros genéticos; produção animal; qualidade da carne; seleção; ultrassonografia. 


\section{Introduction}

Ultrasonography is an easy-to-apply technique of fast and cost-effective implementation. This tool is commonly used to obtain information on carcass quality in live animals. Several studies confirm the potential of ultrasonography in goat breeding, and their results have been useful for genetic selection (Cartaxo and Sousa et al., 2008; Suguisawa et al., 2009; Figueiredo Filho et al., 2012).

Ultrasound-measured carcass traits, especially in cattle and sheep, show moderateto-high positive genetic correlation with the same traits obtained after slaughtering (Cartaxo and Sousa et al., 2008; Polizel Neto et al., 2009; McManus et al., 2013). However, this information is still poorly understood in meat goats. Only few studies have been conducted using ultrasonography in goats to obtain carcass information and estimate both (co)variance components and genetic parameters for these traits via Bayesian methods.

Therefore, this study aimed to estimate (co) variance components and genetic parameters for ultrasound-measured carcass traits and body size in Anglo-Nubian breed goats raised in the Mid-North region of Brazil, using single- and two-trait analyses via Bayesian inference.

\section{Materials and methods}

\section{Ethical considerations}

The experimental procedures for this study were approved by the Animal Care and Use Committee (Federal University of Piauí, Brazil; process \#009/14).

\section{Animals, location and data}

The dataset consisted of pedigree and production records from Anglo-Nubian goats (males and females older than seven months of age) raised in the States of Piauí and Maranhão (Mid-North region of Brazil) and registered in the goat breeders'associations, totaling 457 ani- mals (before quality control). Data measurement was carried out in the period 2012-2014. In most herds, animals were raised in extensive production systems, grazing on native or cultivated pasture and receiving supplement feed when the pasture was in short supply, in addition to water and mineral salt ad libitum.

The following morphometric measurements were collected: rump height ( $\mathrm{RH}$, measured from the ileum sacral tuberosity to the ground); chest circumference $(\mathrm{CC}$, measured at the outer circumference of the thoracic cage, near the axilla); chest depth $(\mathrm{CD}$, taken as the difference between the height at withers and the height from the sternum to the ground); and leg perimeter (LP, measured on the median part of the leg above the femoro-tibio-patellar joint). All data related to morphometry were measured in centimeters $(\mathrm{cm})$ while the animal was in standing position. Body weight was measured using a scale (200-kg capacity; 1-gram accuracy).

Carcass composition was evaluated based on the following traits: loin eye area (LEA, measured in $\mathrm{cm}^{2}$ ); loin-eye length and maximum depth (LEL and LED, respectively; indicative of the extent of carcass muscling; both in $\mathrm{cm}$ ); and subcutaneous fat thickness in the sternum (FTS, in the mediastinal sternal region; $3^{\text {rd }}$ bone of the sternum; in $\mathrm{mm}$ ), as proposed by Figueiredo Filho et al. (2012). Carcass traits were evaluated via ultrasound images of the crosssection of the longissimus dorsi muscle between the $12^{\text {th }}$ and $13^{\text {th }}$ lumbar vertebrae, using an ultrasound (model Chison 600M) device equipped with a linear transducer $(5.0-\mathrm{MHz} ; 13 \mathrm{~cm})$. Images were displayed and immediately interpreted. For the best image quality, and in the interest of animal welfare, goats were restrained in a comfortable standing position.

Data were grouped into two seasons, according to the month. Thus, data collected within the Jan-May and Jun-Dec periods corresponded to rainy and dry seasons, respectively. Similarly, the months of birth of animals were grouped into two birth seasons (rainy and dry). Animal ages at the time of data collection were grouped into 
three different age classes (AC): AC 1 (animals older than six months and younger or equal than two years), AC 2 (animals older than two years and younger or equal than three years), and $\mathrm{AC}$ 3: (animals older than three years). Finally, the goats evaluated were grouped into animal categories, namely: pregnant does, kidding does, non-pregnant does, and breeding bucks. Animals born on the same farm, in the same year, and of the same sex were considered in the formation of the contemporary groups.

\section{Statistical analyses}

Data quality control was performed using the SAS software, version 9.0 (Cary, NC, USA, 2002). After the consistency analysis, a file was created with information of animals, parents, contemporary groups, year of collection, age class, animal category, and study traits, having data from 385 animals (330 females and 55 males). At the end, the relationship matrix contained 793 animals.

Components of (co)variance and genetic parameters for carcass, size, and body weight traits were estimated in single- and two-trait analyses in a linear mixed animal model via Bayesian methodology. The traits were combined two by two (total: 36 different analyses) and were analyzed assuming a normal distribution.

In matrix notation, the linear mixed animal model is represented as $\mathrm{y}=\mathrm{X} \beta+\mathrm{Z} \alpha+\varepsilon$, where $\mathrm{y}$ is the observation vector of the traits in study; $X$ is an incidence matrix with dimension $n \times m$ ( $n$ is the number of observations, and $m$ is the number of classes of fixed effects), which associates records to fixed effects; $\beta$ is the vector of sistematic effects of contemporary group (farm, birth year, birth season, and collection period), year of collection, age class, and animal category; $\mathrm{Z}$ is the incidence matrix $\mathrm{n} \times \mathrm{N}$, which associates records to direct additive genetic effects ( $n$ is the total number of observations, and $\mathrm{N}$ is the number of individuals); $\alpha$ is the vector of direct additive genetic effects of each animal (animal model); and $\varepsilon$ is the vector of residual random errors associated to the records.
The assumptions for the uni-trait analysis under the Bayesian approach are: $\mathrm{y}\left|\beta, \alpha, \sigma_{\mathrm{e}}^{2} \sim \mathrm{N}\left(\mathrm{X} \beta+\mathrm{Z} \alpha+\mathrm{I} \sigma_{\mathrm{e}}^{2}\right), \alpha\right| \mathrm{A}, \sigma_{\mathrm{a}}^{2} \sim \mathrm{N}\left(0, \mathrm{~A} \sigma_{\mathrm{a}}^{2}\right)$, and $\mathrm{e} \mid \mathrm{e}, \sigma_{\mathrm{e}}^{2} \sim \mathrm{N}\left(0, \mathrm{I} \sigma_{\mathrm{e}}^{2}\right)$, where $\sigma_{\mathrm{a}}^{2}$ and $\sigma_{\mathrm{e}}^{2}$ are components of the additive direct and residual variances, respectively; A is the numerator relationship matrix; I is the identity matrix of equal order to the number of animals with information; and other previously defined symbols.

Intwo-traitanalysis, thesamelinearmodelofthe single-trait analysis was used with the following assumptions: $\quad \mathrm{y} \mid \beta, \mathrm{a}, \mathrm{G}_{0}, \mathrm{R}_{0} \sim \mathrm{N}\left(\mathrm{X} \beta+\mathrm{Za}, \mathrm{R}_{0} \otimes \mathrm{I}\right)$, $\mathrm{a} \mid \mathrm{G}_{0}, \mathrm{~A} \sim \mathrm{N}\left(0, \mathrm{G}_{0} \otimes \mathrm{A}\right), \quad$ and $\quad \mathrm{e} \mid \mathrm{R}_{0} \sim \mathrm{N}\left(0, \mathrm{R}_{0} \otimes \mathrm{I}\right)$, where $A$ is the numerator relationship matrix; $\mathrm{I}$ is the identity matrix of equal order to the number of animals with information; R_(0 )is the residual (co)variance matrix among traits, and other previously defined symbols. Usually, $\beta$ assumes non-informative prior (flat) distribution because there is no distinction between fixed and random effects in the Bayesian context. Thus, $p$ ( $\beta) \alpha$ is a constant.

The model parameters were estimated via Bayesian inference using the GIBBS1F90 program (Misztal et al., 2002). Chains with two and four million iterations were first used. However, a two million length chain was used to generate the distribution of (co)variance components and genetic parameters of the study traits since both lengths resulted in similar estimates. According to Cardoso et al. (2008), this is considered a convergence criterion.

After the burn-in of the first one million samples, a sample was collected from every 250 samples (thinning interval) resulting in a posterior distribution with 4,000 samples, in which inferences were performed. The burnin and thinning interval were determined in preliminary tests to assess convergence and sample distribution using the POSTGIBBS1F90 program (Misztal et al., 2002).

The Geweke's (1992) convergence diagnostic and Monte Carlo error (MCE) analysis were used to monitor convergence of the Markov chain Monte Carlo (MCMC) method. The MCE 
was obtained by calculating the variance of samples taken for each component divided by the number of samples. Thus, the square root of this value is an approximation to the standard deviation of the error associated with Gibbs chain length (Van Tassel and Van Vleck, 1996).

\section{Results}

The coefficients of variation (CV) for LEA, LED, LEL, and FTS were within the range 20.3-40.0. The CV values for carcass traits were higher than those obtained for morphometric traits (Table 1).
The Geweke's convergence diagnostic values (Table 2) enabled us to infer that chains converged at the significance level (0.05) in all parameters. This indicates that the number of iterations was adequate and the posterior sampling values are valid estimates for the posterior distribution of parameters. Values above the significance level indicate convergence problems of the parameter chain (Geweke et al., 1992). In addition, the values calculated for MCE were low.

Convergence was achieved for the heritability coefficients obtained using two-trait analyses according to the Geweke's convergence diagnostic $(\mathrm{p}<0.05)$ and MCE values (Table 3).

Table 1. Descriptive statistics of carcass, body size, and body weight traits in Anglo-Nubian goats.

\begin{tabular}{lccccc}
\hline Trait & Mean & CV & $\boldsymbol{s}^{\mathbf{2}}$ & Min range & Max range \\
\hline LEA $\left(\mathrm{cm}^{2}\right)$ & 5.90 & 40.02 & 5.58 & 1.74 & 19.03 \\
LED $(\mathrm{cm})$ & 2.25 & 20.32 & 0.21 & 1.27 & 4.19 \\
LEL $(\mathrm{cm})$ & 3.13 & 22.46 & 0.49 & 1.46 & 6.01 \\
FTS $(\mathrm{mm})$ & 6.10 & 29.27 & 3.19 & 1.67 & 14.24 \\
RH $(\mathrm{cm})$ & 72.92 & 7.63 & 30.98 & 53.00 & 92.00 \\
CC $(\mathrm{cm})$ & 85.81 & 9.15 & 61.70 & 64.00 & 112.00 \\
CD $(\mathrm{cm})$ & 32.73 & 19.05 & 38.88 & 8.00 & 56.00 \\
LP $(\mathrm{cm})$ & 35.15 & 13.44 & 22.42 & 10.00 & 53.00 \\
Body weight $(\mathrm{kg})$ & 51.75 & 30.43 & 247.96 & 25.00 & 107.00 \\
\hline
\end{tabular}

CV: coefficient of variation; $s^{2}$ : variance. LEA: loin eye area; LED: loin eye depth; LEL: loin eye length; FTS: fat thickness of the sternum; RH: rump height; CC: chest circumference; CD: chest depth; LP: leg perimeter.

Table 2. Average estimates of direct additive genetic variance $\left(\sigma_{a}^{2}\right)$, residual variance $\left(\sigma_{e}^{2}\right)$, and heritability coefficients $\left(\mathrm{h}^{2}\right)$ of carcass, body size, and body weight traits obtained by single-trait analysis in Anglo-Nubian goats.

\begin{tabular}{lccccc}
\hline Trait & $\boldsymbol{\sigma}_{\boldsymbol{a}}^{2}$ & $\boldsymbol{\sigma}_{\boldsymbol{e}}^{2}$ & $\boldsymbol{h}^{\mathbf{2}}$ & Geweke $(\boldsymbol{p}$-values $)$ & MCE \\
\hline LEA & 0.39 & 1.77 & 0.16 & 0.00 & 0.0019 \\
LED & 0.03 & 0.07 & 0.27 & 0.01 & 0.0023 \\
LEL & 0.02 & 0.24 & 0.08 & 0.01 & 0.0012 \\
FTS & 0.39 & 2.20 & 0.17 & 0.02 & 0.0019 \\
RH & 3.33 & 8.79 & 0.27 & 0.00 & 0.0024 \\
CC & 3.98 & 24.48 & 0.14 & 0.00 & 0.0016 \\
CD & 1.37 & 12.98 & 0.09 & 0.03 & 0.0059 \\
LP & 1.87 & 11.79 & 0.13 & 0.02 & 0.0016 \\
Body weight & 33.51 & 59.85 & 0.35 & 0.00 & 0.0027 \\
\hline
\end{tabular}

MCE: Monte Carlo error for mean posterior heritability; LEA: loin eye area; LED: loin eye depth; LEL: loin eye length; FTS: fat thickness of the sternum; RH: rump height; CC: chest circumference; CD: chest depth; LP: leg perimeter. 
The estimates of direct additive variances and heritability coefficients in two-trait analyses (Table 3) were higher than those obtained using single-trait analyses (Table 2) for all traits.

Heritability coefficients estimated for all traits ranged from low to moderate magnitude (Table 3). The increase in the amount of information in two-trait analyses directly influenced the estimated heritability averages for all traits (Table 3). However, this increase was low, ranging from 5.88 to $38.09 \%$, and the magnitudes of heritability estimates ranged from low to moderate.

Regarding the estimates of two-trait analyses, among the muscularity traits in study, loin eye depth had the highest heritability estimate (0.29), thus indicating that this trait can be included in selection indexes. The $\mathrm{h}^{2}$ value (0.32) for rump height also suggests that this trait has enough genetic variation to respond to selection in Anglo-Nubian goats, especially if associated with further development of leg, which has cuts of high commercial value. The average $h^{2}$ value for loin eye length was low (0.11). The phenotypic variance is thus largely explained by the environmental component effect. Therefore, selection for this trait would not result in significant gains in meat production. The heritability estimates for other morphometry traits also ranged from low to moderate magnitude (0.14-0.21).

Table 3. Estimates of direct additive genetic variance $\left(\sigma_{a}^{2}\right)$, residual variance $\left(\sigma_{e}^{2}\right)$, and heritability coefficients $\left(\mathrm{h}^{2}\right)$ of carcass, body size, and body weight traits obtained by two-trait analysis in Anglo-Nubian goats.

\begin{tabular}{lccccc}
\hline Trait & $\boldsymbol{\sigma}_{\boldsymbol{a}}^{2}$ & $\boldsymbol{\sigma}_{\boldsymbol{e}}^{2}$ & $\boldsymbol{h}^{\mathbf{2}}$ & Geweke $(\boldsymbol{p}$-values $)$ & MCE \\
\hline LEA & 0.37 & 1.76 & 0.17 & 0.05 & 0.0019 \\
LED & 0.09 & 0.07 & 0.29 & 0.02 & 0.0024 \\
LEL & 0.03 & 0.22 & 0.11 & 0.01 & 0.0013 \\
FTS & 0.44 & 1.79 & 0.19 & 0.00 & 0.0019 \\
RH & 3.99 & 8.42 & 0.32 & 0.03 & 0.0026 \\
CC & 5.65 & 23.52 & 0.19 & 0.03 & 0.0018 \\
CD & 2.03 & 12.67 & 0.14 & 0.00 & 0.0014 \\
LP & 3.00 & 11.10 & 0.21 & 0.02 & 0.0019 \\
Body weight & 41.57 & 55.19 & 0.42 & 0.01 & 0.0026 \\
\hline
\end{tabular}

MCE: Monte Carlo error for mean posterior heritability; LEA: loin eye area; LED: maximum loin eye depth; LEL: maximum loin eye length; FTS: fat thickness sternum; RH: rump height; CC: chest circumference; CD: chest depth; LP: leg perimeter.

Estimates of genetic correlations between loin eye area, loin eye depth, and loin eye length had high magnitude (Table 4). Therefore, there is a genetic association between these traits, i.e., the same gene sets for additive action influence the expression of these phenotypes.

The coefficients of genetic correlation between carcass and morphometric traits had different magnitudes (Table 4). The loin eye area was highly correlated with leg perimeter (0.60). Thus, there is potential to achieve genetic progress through indirect selection of prime cuts based on leg perimeter, which is easy to measure and has moderate heritability (Table 3). The negative genetic correlation between fat thickness in sternun and morphometric measurements ranged from low to moderate magnitude. This finding indicates that subcutaneous fat reduction for larger body measurements is possible (Table 4). Low correlation coefficients between chest depth and carcass traits and close-to zero coefficients of genetic correlation between body weight and loin eye area were found (Table 4). 
Table 4. Coefficients of genetic correlation between carcass and body size traits in Anglo-Nubian goats.

\begin{tabular}{lcccccccc}
\hline Traits & LEA & LED & LEL & FTS & RH & CC & CD & LP \\
\hline LED & 0.86 & - & & & & & & \\
LEL & 0.93 & 0.78 & - & & & & & \\
FTS & 0.27 & 0.26 & 0.41 & - & & & & \\
RH & 0.12 & 0.24 & 0.00 & -0.45 & - & & & \\
CC & 0.45 & 0.59 & 0.20 & -0.32 & 0.72 & - & - & - \\
CD & -0.31 & 0.12 & 0.06 & -0.05 & 0.54 & -0.06 & -0.32 & -0.64 \\
LP & 0.60 & 0.09 & 0.22 & -0.34 & 0.55 & 0.56 & \\
Body weight & 0.01 & 0.41 & 0.27 & 0.00 & 0.44 & 0.76 & -0.38 & 0.64 \\
\hline
\end{tabular}

LEA: loin eye area; LED: maximum loin eye depth; LEL: maximum loin eye length; FTS: fat thickness sternum; RH: rump height; CC: chest circumference; CD: chest depth; LP: leg perimeter.

\section{Discussion}

The average values of loin eye area $(5.90$ $\left.\mathrm{cm}^{2}\right)$ and depth $(2.25 \mathrm{~cm})$ were lower (Table 1) than those found in a study of carcass traits in goats (loin eye area $8.22 \mathrm{~cm}^{2}$ and loin eye depth $5.05 \mathrm{~cm}$ ) (Albuquerque et al., 2015). The averages for loin eye depth $(2.25 \mathrm{~cm})$ (Table 1) were higher than those reported by Gomes et al. (2011) for crossbred Anglo-Nubian $\mathrm{x}$ Alpine $(1.79 \mathrm{~cm})$ and TriCross (Boer x Alpine x Anglo-Nubiana; $1.88 \mathrm{~cm}$ ) goats with 110 days average age and raised under confinement. The difference between these values may be due to the higher age of the animals evaluated in the present study (mean age: 2.5 years).

The mean sternal subcutaneous fat thickness (6.10 mm; Table 1) observed in this study can be explained by earlier fat deposition in this region compared to the fat thickness measured in the longissimus dorsi muscle (FurushoGarcia et al., 2009). The fat thickness values in the sternum (FTS) were similar to those found by Figueiredo Filho et al. (2012), who evaluated carcass traits with ultrasonography in Boer $\mathrm{x}$ Anglo-Nubian goats and considered sternal subcutaneous fat as a suitable alternative for assessing carcass quality of field-raised goats. In addition, Fernandez et al. (2016) observed high linear correlation $(r=0.73)$ between FTS and total proportion of body fat, compared to lower back fat. Moreover, subcutaneous fat may indicate the presence of energy stored during the food shortage period in Brazil's Northeast region.

The coefficients of variation of LEA, LED, and LEL indicate that carcass measurements obtained by ultrasonography are influenced byf several factors, e.g., physiological status and nutritional condition of animals, as well as operator skill to use the ultrasound device. These findings also characterize the presence of phenotypic variability in these traits, which is important in animal breeding programs for selection based on carcass measures in live animals. Thus, it is important to know the components of (co)variance associated with these traits.

The values obtained in the Geweke's convergence diagnostic and MCE calculation (Table 2) indicate a convergence of the heritability coefficients estimates (h2) in posterior distributions and confirm that the sample chain size used in the Bayesian analysis was enough to obtain accurate estimates of the posterior density averages. According to Van Tassel and Van Vleck et al. (1996), the MCE value (Table 2) is low when it is added to the average estimate of posterior distribution of heritability coefficients, and does not change the result of this estimate. It is necessary to verify this value in order to determine whether the posterior means for marginal distributions of the (co)variance components and genetic parameters were generated (Faria et al., 2015). 
The estimatives of direct additive variances and heritability coefficients in two-trait analyses were high (Table 3) due to the increased amount of information analyzed, which allowed to explore two by two the correlation between all traits and recover part of the direct additive genetic variance incorporated in the residual variance, as also observed by Santos et al. (2013). Thus, better estimates of genetic components were obtained from the phenotype.

Regarding the average estimates obtained using two-trait analyses, the additive genetic variance for muscularity (LEA, LED, and LEL) and finishing (FTS) traits obtained using this type of analysis were low in relation to the total variation (Table 3 ). These findings show that a large part of the total variation has an environmental origin. A similar result was obtained for morphometric traits. It is noteworthy that the low values for the additive genetic variance of evaluated traits may indicate that herds were little subjected to animal breeding actions for these traits.

The use of multi-trait models is directed to reduce the bias caused by the sequential selection (Sarmento et al., 2006). Therefore, it is recommended to use this type of analysis for the genetic study of all the traits evaluated. In the current study, higher heritability values were obtained using a two-trait analysis.

The heritability coefficient estimates (Table 3) are similar to those reported in studies for these same traits in sheep and goats (Figueiredo Filho et al., 2012; Jucá et al., 2016; Sena et al., 2016). It is possible to include these traits in meat goat breeding programs, considering the traits with bigger heritability coefficients. However, little genetic gain will likely be achieved in the short-term. It is expected that individual selection will provide satisfactory genetic effects as the selection process is intensified. The heritability estimates could be improved if the residual variance could be reduced by means of better control of environmental effects.
The phenotypic variations in loin eye area and sternal fat thickness were highly affected by environmental effects. Better control of these factors is necessary for greater expression of the gene set responsible for these traits. Such control on the evaluated animals was hardly noticed because they were raised in an extensive system.

According to Robertson et al. (1959), two traits should be considered in selection programs if the genetic correlation between them is around 0.80 . The result in Table 4 indicates that at least one of the traits (LEA, LED, or LEL) may be excluded from the selection process to facilitate genetic evaluations. Regarding heritability estimates of traits measured in the longissimus dorsi muscle, the loin eye length can be discarded as a selection criterion due to its low heritability (0.11) (Table 3). The sternal fat may also be considered informative since the subcutaneous fat layer may indicate the nutritional status of the animal for its maintenance and precocity. In addition, the sternal region is an area of considerable fat deposition in goats, which occurs earlier in life compared to fat deposition in the lower back region. The positive genetic correlations between sternal fat thickness and loin eye area $(0.27)$, loin eye depth $(0.26)$, and loin eye length $(0.41)$ (Table 4$)$ indicate that fat deposition in the brisket region tends to increase when muscularity traits are included in the selection indexes of Anglo-Nubian goats.

The genetic correlation between loin eye area and leg perimeter (Table 4) indicates that this second trait can be used if carcass measurement is difficult. In addition, leg perimeter can be used for direct selection of prime cuts with high commercial value since this trait showed moderate heritability (Table 3). However, LP-based indirect selection of LEA may not provide satisfactory gains. But, including loin eye area as a selection criterion in genetic evaluation programs is important. Similarly, intermediate correlation was found between chest circumference and loin eye depth (0.59), which is the muscularity trait with the 
highest heritability coefficient (Tables 2 and 3 ). However, direct selection is recommended for LED because CC-based indirect selection for LED may not result in adequate gains. Since leg perimeter is positively related to loin eye area and negatively related to fat thickness in sternum (Table 4), a suggestion is to use economic values for these traits in selection indexes.

Heritability coefficients for CD also showed low values (Tables 2 and 3); thus, this trait is not indicated for selection of Anglo-Nubian goats for meat production. In addition, the genetic correlation between CD and LEA was negative (-0.31), which suggests that selection of animals with low chest capacity will result in greater loin eye measures, therefore higher carcass yield.

Similar to Ferreira et al. (2014) findings, rump height values ranged from average to high magnitudes for genetic correlation with other morphometric traits. Thus, rump height is the only morphometric trait in a study that is recommended to compose selection indexes. Despite the low correlations between $\mathrm{RH}$ and LEA (0.12), LED (0.24), LEL (0.00), and FTS $(-0.45)$, rump height has moderate heritability and should thus compose the selection criteria for goat meat production.

In theory, heavier goats are expected to have more muscle. However, the genetic correlation between body weight and loin eye area was close to zero (Table 4). Furthermore, genetic correlations between body weight and morphometric measurements and other carcass traits indicate that body weight is not a good indicator of carcass muscularity. Therefore, selection of animals based on higher body weight may not result in genetic improvement of Anglo-Nubian goats for meat production. So, breeders who explore this breed in extensive systems in the Mid-North region of Brazil will not assure genetic gain for muscularity if they use only body weight as selection criterion. An alternative to solve this issue is the inclusion of a criterion directly related to muscularity information in the selection index.

Based on results showed in Table 4 , it is possible to infer that some genes responsible for the phenotypic expression of muscularity traits are also responsible for the expression of morphological traits, such as leg perimeter and chest circumference. Considering the correlations among chest depth, leg perimeter, rump height, and chest circumference (Table 4), the circumference and perimeter measurements are apparently better than length and depth measures to infer about carcass yield and quality. This can be justified because perimeter and circumference measurements include the muscularity, whereas length and depth are measured in bone extremities, which are close to a greater amount of bone tissue. However, further studies are necessary to confirm this association, especially in meat goats.

Heritability estimates (Table 3 ) indicate that perimeter and circumference traits are suitable to compose selection indexes. Furthermore, it is possible to achieve correlated responses of these traits with loin eye area, loin eye depth, and loin eye length (Table 4).

Therefore, we conclude that two-trait analyses via Bayesian models provide good estimates of (co)variance components and genetic parameters for ultrasound-measured carcass traits and body size traits in goats. Heritability estimates for carcass traits obtained by real-time ultrasound in Anglo-Nubian goats indicate that the inclusion of these traits in goat meat breeding programs could enable breeders and professionals to identify animals with better genotypes for muscularity and finishing. The inclusion of leg perimeter and chest circumference in selection indexes will allow breeders to achieve indirect genetic gains in muscularity traits. Body weight may not be the best trait for indirect selection for qualitative and quantitative carcass traits in meat goats. However, further studies are necessary to verify their genetic relationship. 


\section{Declarations}

\section{Funding}

This study was funded by Universidade Federal do Piauí, with the support of Coordenação de Apefeiçoamento de Pessoal de Nível Superior and Instituto Federal de Educação, Ciência e Tecnología do Maranhão, Brazil.

\section{Conflicts of interest}

The authors declare they have no conflicts of interest regarding the work presented in this report.

\section{Author contribution}

Conception and design of study: Luiz AS FigueiredoFilho; José LR Sarmento; José EG Campelo; Natanael PS Santos; Luciano S Sena; Tatiana S Torres.Acquisition of data: Luiz AS FigueiredoFilho; José LR Sarmento; José EG Campelo; Natanael PS Santos; Luciano S Sena; Tatiana S Torres.

Analysis and/or interpretation of data: Luiz AS FigueiredoFilho; José LR Sarmento; José EG Campelo; Natanael PS Santos; Luciano S Sena; Tatiana S Torres.

Drafting the manuscript:LuizASFigueiredoFilho; José LR Sarmento; José EG Campelo; Natanael PS Santos; Luciano S Sena; Tatiana S Torres.

Criticalreview/revision:LuizASFigueiredoFilho; José LR Sarmento; José EG Campelo; Natanael PS Santos; Luciano S Sena; Tatiana S Torres.

\section{References}

Albuquerque IA, Villarroel ABS, Pereira ES, Teixeira MC, Silva EMC, Pimentel PG, Oliveira SMP. In vivo and carcass characteristics of goats and sheep oi: sold for slaughter in Ceará State. Semina: Ciênc Agrár 2015; 36(5):3369-3382. DOI: https://doi.org/10.5433/1679-0359.2015v36n5p3369

Cardoso FF. Manual de utilização do programa INTERGEN: versão 1.0 em estudos de genética quantitativa animal. Bagé: Embrapa Pecuária Sul, 2008.
Cartaxo FQ and Sousa WH. Correlations between traits obtained by real time ultrasound and those obtained in the carcass of feedlot finished lambs. Rev Bras Zootec 2008; 37(8):1490-1495.

Faria CU, Andrade WBF, Pereira CF, Silva RP, Lôbo RB. Bayesian analysis for carcass traits in Polled Nelore. Ciênc Rural 2015; 45(2):317-322. DOI: https://doi.org/10.1590/0103-8478cr20140331

Ferreira TA, Peireira IG, Gouveia AMG, Pires AV, Facó O, Farah MM, Pessoa MC, Guimarães MPSLPM. Genetic evaluation of Saanen goats born in Brazil from 1979 to 2009. Arq Bras Med Vet Zootec 2014; 66(4):1179-1188. DOI: https://doi.org/10.1590/1678-6154

Fernandes AFA, Oliveira JA, Queiroz AS. Body condition score in ruminants. Ars Vet 2016; 32(1):55-66.

Figueiredo Filho LAS, Sarmento JLR, Campelo JEG, Santos NPS, Sousa Júnior A. Measures Carcass traits by ultrasound in goats. Rev Bras Saúde Prod Anim 2012; 13(3):804-814. DOI: https://doi.org/10.1590/S1519-99402012000300018

Furusho-Garcia IF, Perez JRO, Pereira IG, Costa TIR, Martins MO. Allometric study on carcass tissuesfrompurebredSantaInêslambsorcrossbred with Texel, Ile de France and Bergamácia. Rev Bras Zootec 2009; 38(3):539-546. DOI: https://doi.org/10.1590/S1516-35982009000300020

Geweke J. Evaluating the accuracy of samplingBased approaches to calculating posterior moments. Bayesian Stat 1992, Oxford: Oxford University Press, 4.

Gomes HFB, Menezes JJL, Gonçalves HC, Cañizares GIL, Medeiros BBL, Polizel Neto A, Louençon RV, Chávari ACT. Carcass traits of characteristics of kid goats from five breed groups raised in a feedlot system. Rev Bras Zootec 2011; 40(2):411-417. DOI: https://doi.org/10.1590/S1516-35982011000200024 
Jucá AF, Faveri JC, Melo Filho GM, Ribeiro Filho AL, Azevedo HC, MunizEM, Pedrosa VB, PintoLF. Effects of birth type and family on the variation of carcass and meat traits in Santa Ines sheep. Trop Anim Health Prod 2016; 48(2):435-443. DOI: https://doi.org/10.1007/s11250-015-0971-8

McManus C, Paim TP, Louvandini H, Dallago BSL, Dias LT, Teixeira RA. Ultrassonography evaluation of sheep carcass quality of Santa Inês breed. Ciênc Anim Bras 2013;14(1):8-16. DOI: https://doi.org/10.5216/cab.v14i1.12336

Misztal J. Fortran Programs. Disponível em: http://nce.ads.uga.edu/wiki/doku.php?id=readme.gib $\underline{\text { bs } 3,2012}$

Polizel Neto A, Jorge AM, Moreira PS, Gomes HFB, Pinheiro RSB, Andrade EM. Correlations among ultrasound measurements and on carcass of the steers finished on pasture. Rev Bras Saúde Prod Anim 2009; 10(1):137-145.

Robertson A. The sampling variance of the genetic correlation coefficient. Biometrics 1959; 15(3):469-485.

Santos NPS, Sarmento JLR, Pimenta Filho EC, Campelo JEG, Figueiredo Filho LAS, Sousa Júnior SC. Environmental and genetic aspects of litter size in goats using linear and threshold Bayesian models. Arq Bras Med Vet Zootec 2013; 65 (3):885-893. DOI: https://doi.org/10.1590/S0102-09352013000300038
Sarmento JLR, Torres RA, Sousa WH, Pereira CS, LopesOS, Breda FC. Estimation of genetic parameters for growth traits of Santa Inês sheep using single and multiple-trait models. Arq Bras Med Vet Zootec 2006; 58(4):581-589. DOI: https://doi.org/10.1590/S0102-09352006000400021

SAS. Statistical analysis systems user's guide: Version 9.0. Cary, NC, USA: SAS Institute Inc. 2002.

Sena LS, Santos GV, Torres TS, Sousa Júnior A, RegoNetoAA, Sarmento JLR, Biagiotti D. Genetic parameters for carcass traits and body size of meat sheep. Semina: Ciênc Agrár 2016; 37(4):2477-2486. DOI: https://doi.org/10.5433/16790359.2016v37n4Sup11p2477

Suguisawa L, Marques ACW, Bardi AE, Fausto D. Utilization of ultrasonography as a tool for standardization of commercial carcasses. Tec Ciênc Agropec 2009; 3(4):55-65.

Van Tassell CP and Van Vleck LD. Multipletrait Gibbs sampler for animal models: flexible programs for Bayesian and likelihood-based covariance component inference. J Anim Sci 1996; 74(11):2586-2597. 